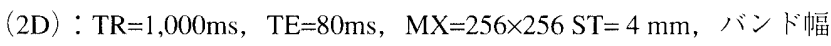
$=781 \mathrm{~Hz} / \mathrm{Px}$ ETS $=3.98 \mathrm{~ms}$

【方法】正常人ボランティア 1 名を心電図同期下，心拡張期時の Trigger Delay Timeをかえて動静脈画像，静脈画像を得る。その画像 をサブトラクション処理することにより動脈画像を作成した。 (1) 位 相エンコード方向を変化させることにより描出される血管に違いが あるか比較，検討した。 (2) 正常人ボランティアを用いて血管が最も よく描出される最適なdelay Timeを求めた。 (3) 従来法 (TOF) と今回 作成したMRA画像を視覚的に比較した. (4)で同様に撮像し画像に 違いがあるか比較，検討した。

【結果】サブトラクション処埋した画像での動脈の描出は良好だった が静脈は不良だった。収縮期時の画像撮像時にBlack Bloodパルス を使用して撮像し，それとサブトラクション処理することにより静 脈の描出は良好になった。空間分解能を良好にさせると，SNRの低 下，ETSの延長により師流をうまく描出できなくなった。

【考察】TOFとを比較すると分解能に制限があり，画像処埋が煩雑で あったもののTOFに比べ方向依存性の少ない画像が非造影下にて明 瞭に描出することができた，当院の使用装置でもある程度まではこ の方法でMRAが撮像可能であったので非造影MRAの選択肢が増 え, 今後の臨床応用に期待できる。

293 Balanced-TFEにおけるShot-IntervalとShot数の違いによる 信号変化について

東海大学医学部付属病院放射線技術科 室伊三男，堀江朋彦 花木 昭, 木村絵里, 松尾太一

【目的】Balanced-FFE (steady-state free precessıon : 以下SSFP) の位相工 ンコードを分割して收集 (multı shot)するBalanced-TFE（以下B-TFE) は非造影MRAに用いられている。この撮像法は縦磁化がshotごとに 回復するため，厳密にはSSFPがShotごとに崩れる，今回われわれ は，SSFPが崩れることにより，信号がどのように変化するかについ て検討したので報告する。

【原埋】B-TFEにおいてT,の非常に長いものは，Shotごとの縦傢化の 回復を無視できるために横磁化の定常状態は維持される。しかしT、 の短いものは定常状態がくずれ，1 shotのデー夕収集中にSSFPに移 行する過程をたどる。したがって対象物のT1, Shot数, Shot-Interval の違いによって信号が変化する。

【方法】水と油の溶液を用い, Shot数, Shot-Interval, エンコード方法 (low-high/lnear) 変えてB-TFEで撮像し, 水と油の信号変化を求め た。

【結果】エンコード法がlow-highでShot数204において, Shot-Intervalが 短いほど $(600 〜 3,000 \mathrm{msec})$ 油の信号は高くなった. Shot-Interval 3,000msecでShot数204ではlow-highよりlinearの脂肪信号が高信号に なったＳhot数が少なくなるとartifactが出現した．1 shot当りに60以 上のダミーパルスを付加すると信号変化はなくなった。

【考察】B-TFEではShot-Intervalによって水と油の信号強度が変化し， low-highの方がその影響は顕著に現れる。この原理を逆に利用し， SSFP移行期にデー夕を収集することによって脂肪信号を抑制した撮 像が可能となった。

294 Balanced Sequenceに用いる脂肪抑制法(LCSSFP法)の検討 - 1.0 Tに扔ける脂肪抑制効果についてー

聖マリアンナ医科大学横浜市西部病院・画像診断部 犬飼 博 岡村隆徳, 宮崎寿哉, 菊池康隆, 大城和巳 聖マリアンナ医科大学病院・画像診断センター 馬野清次

【目的】従来, 当院における腹部非造影MRA検査は, SPIR法やProset 法などの脂肪抑制併用のsteady state coherent 1maging sequence (balanced-TFE/FFE)で撮像している。今回われわれは, Linear Combination Steady State Free Precessıon法(LCSSFP法)の導入に伴い,
その脂肪抑制効果について検討した。

【使用機器】PHILIPS intera 1.0T power

【方法】1)自作ファントムおよび健常ボランティアの腹部を撮像し, LCSSFP法に扔ける脂肪抑制効果をTR/TEを变化させて倹討した．2） LCSSFP法に最適なTR/TEを設定し，他の脂肪抑制法と比較検傠し た.

【結果】LCSSFP法の脂肪抑制効果はProset法とほぼ同程度であった。 また, Proset法に比べLCSSFP法はsusceptibility artifactが少なかった。 【結語】今回の実験で1.0Tの沉用機に扔けるLCSSFP法の脂肪抑制効果 が確認され，腹部非造影MRA検查の脂肪抑制法としてLCSSFP法が 有用であることが示唆された。

\section{5 非造影による下肢アンギオの検討}

偕行会名古屋共立病院 山田雅已，岩瀬幹生，山室 修，滝川幸則 池ノ上宙

【目的】造影剤を用いた下肢アンギオは現在広く行われている。そこ でわれわれは，MRI装置を使用したTOF法で造影剂を使用せず下肢 アンギオを描出するための至的条件を検討した。

【使用機器】MRI装置：GE社製Sıgna MR/1 EchoSpeed 1.5T，コイル： TORSOコイル(サーフェスコイル)

【撮像シーケンス】2D-TOF SPGR, Bandwidth：1563, FOV：35, Slıce Thickness $5 \mathrm{~mm}$ Over lap : $1 \mathrm{~mm}$, Matrıx : 256×160, 摄像時 間：約 8 分 ( 1 ポジション), 心電同期併用

【対象】 24 歳〜 45 歳の健常者男女 5 人で検討を行った。

【实験方法】前述の撮像シーケンスのうち今回は二つの条件, Flip Angle值を $45,60,75,90^{\circ}$ と 4 ステップ，Views per Segment値を 18, 22，26，30と4 ステップ，それぞれ変える事により描出能を検討し た. また心電同期の誘導タイプは，その都度R-peak Ampを計測し一 番高い値が得られたものを使用した。撮影範囲は腹部大動脈分岐部 上端より下腿動脈下端までの範囲をコイルの感度範囲を考えて $3 つ$ に分け撮影した。

【結果】放射線科医 3 名，診療放射線技師10名による䚵佂では，Flp Angle--45, 60, 75, 90 , Views per Segment值-18，22，26，300) 順に描出が良くFlip Angle 60, Views per Segment值22で撮影した面 像は良好な画像が得られた。

【結語】・ボランティア 5 人による撮影では, Flıp Angle 60, Views per Segment值22で撮影した画像は, 腹部大動脈分岐部上端より前脛 骨動脈, 腓骨動脈, 後脛骨動脈下端まで良好に描出され造影剤を用 いなくても十分な画像が得られた。・感度を高める為にサーフェス コイルを使用したので三つに分けた部位。゙とにコイルの装着をし直 す必要があった。・撮像時間も全体では約25分と造影剂を使用した 場合に比べ時間的な問題も生じた。・今後はこれらを娭討したょで 臨床に応用していきたい。

296 2D PACE法に㧍けるモニタリングの設定パラメータについて 虎の門病院・放射線部 濱田祐介，高橋順士，吉原千治，田野政勝 関みさよ，吉田 孝，村本直樹，渋谷清和，森内啓三郎，竹部英紀 【目的】上腹部MRI検查では, 呼吸停止下の撮像が多用されるが, 設 定パラメータによっては，撮像を分割して行う場合もある。それぞ れ分割した撮像の呼吸停止位置のずれを補正して撮像が行える Prospective Acquisition CorrEction (以下PACE) 法について報告してき た。今回われわれは，モニタリングの設定パラメータが補正精度に 及ぼす影響について検討したので報告する。

【方法】MRI装置はSIEMENS社製MAGNETOM Symphony1.5Tを使用 したＰPACE法の設定パラメータの内，モニタリングの撮像面をコ ロナル，サジタルとアキシャルにそれぞ設定したときの位置ずれ の補正精度を比較した。また，モ二タリングの励起パルスの閐隔を 変化させた場合の撮像時間と補正精度の関係についても検討した。 